\title{
An Investigation of the Turkish Preservice Teachers' Attitudes Towards Individualized Education Program Development Process
}

\author{
M. Abdulbaki KARACA ${ }^{1 *}$ Hasan Huseyin TOPRAK ${ }^{2} \quad$ Yahya ÇIKILI $^{3}$ \\ Necmettin Erbakan University, Ahmet Kelesoglu Education Faculty, Special Education Department, 42090 \\ Konya/Turkey
}

\begin{abstract}
The purpose of the current study was to investigate the attitudes of preservice teachers who study at Turkish universities towards the development process of an individualized education program (IEP). The participants of the study were composed of 304 teachers who were all seniors at the faculties of education in the 2019-2020 academic year. The data were collected through the attitude determination scale (ADS) towards the IEP development process developed by Tike (2007). The scale contained 3 dimensions and 15 items. A Principal Component Analysis revealed a 3 -factor structure of 15 items with a $61,39 \%$ of the total variance explained. In order to determine the internal consistency a reliability test was implemented and the Cronbach Alpha coefficient for the 3 factors was found as .67 . The collected data were analyzed through a statistical analysis program. In order to determine a possible significant difference between the participants' genders, previous interaction with inclusive students, taking inclusive education classes and their attitudes towards IEP development process, an independent variables t-test was implemented. To determine whether there exists a significant difference according to the participants' knowledge of the regulations regarding inclusive education a one-way ANOVA was implemented. When a difference was revealed Tukey test was implemented to determine the differentiation and check the difference between the mean scores. At the end of the study, a statistically significant difference was found regarding the participants' genders, taking inclusive education classes and knowledge of the regulations regarding inclusive education while no statistically significant difference was found according to their previous interaction with inclusive education.
\end{abstract}

Keywords: Individualized education program (IEP), preservice teachers, attitude

DOI: $10.7176 / \mathrm{JEP} / 11-16-11$

Publication date:June 30th 2020

\section{Introduction}

Children with special needs should be ensured to lead an independent life by acquiring social adaptation skills and academic skills. Therefore, it is considered important for individuals with special needs to benefit education services (Baldiris et al., 2016; Batu et al., 2018). Through special education services for individuals with special needs, it is aimed that these individuals can attain their highest performance (Turnbull et al., 2002; Kargin, 2007; Batu, 2015). Individuals with special needs can acquire new skills by means of special education. It is highlighted that especially through inclusive education the social acceptance level of children with normal development is facilitated and individuals with special needs can acquire social skills (Karaca and Efilti, 2019; Batu et al., 2012). In recent years, an increase is observed in the number of children who participate in special education. According to the statistics of the Ministry of National Education in the 2018-2019 academic year, the number of inclusive students in special education classes, special education vocational schools, special education vocational high schools, research and development education, and application centers, inclusive education, and primary and secondary schools open for various disability groups was 398,815 (Ministry of National Education, 2019).

It is emphasized that, in order to achieve the desired benefit in special education implementations, the development of an individualized education program (IEP) for children with special needs is necessary (Darden, 2013; Foster and Cue, 2008). Otherwise, ignoring their individual differences puts them at a disadvantage in education. The inability to meet their needs in the inclusive education process pushes the individuals with special needs out of the system (Özbek, 2005). Despite the onset of the inclusive education implementations in Turkey upon the Children in Need of Special Education Law's entry into force in 1983, it can be seen that in the development of IEP the decree law No. 573 in 1997 was taken as the basis. The mentioned decree-law defines the duties and responsibilities of the IEP development units in Turkey (Official Gazette, 1997). After the laws and regulations, IEP has become a necessity in the education of individuals with special needs (Ministry of National Education, 2018).

IEP provides the educators, who teach the children with special needs, with opportunities for what, where and how to study. For the educators, IEP includes the steps to follow in order to teach the previously determined objectives (Özyürek, 2012). For this reason the teachers who are in the IEP team undertake active roles in the development, implementation, and evaluation of the IEP and they are also counted among the factors that affect the education of individuals with special needs (Aral, 2011; Ministry of National Education, 2013; Gibson, 2015; 
Sanjeev and Kumar, 2007; Karaca, 2018; Erden, 1998; Batu, 2006; Friend and Cook, 2010). For it is stated that the individualized education program refers the concepts such as individual and planned education of individuals with special needs, individual work, fast-paced education, the student's planned study and individual responsibility (Sarıgöz, 2019; Milsom et al., 2007; Mueller and Vick, 2019). Therefore, it is recognized that IEP develops a sense of responsibility in teachers, and for students, it facilitates the speed of learning, improves research skills, increases the level of readiness and improves the academic success (Sarıgöz, 2019).

The teachers should keep in mind that IEP is important in terms of the acquisition of cognitive, affective, and social behaviors by the individuals with special needs (Özyürek, 2004; Y1kmış, 2013; Johns et al., 2002). Especially in inclusive education during the process of the development of an individualized education program, teachers undertake an important role in organizing the teaching adaptations in the classrooms (Odluyurt and Batu, 2013; Allen and Cowdery, 2015; Lewis and Doorlag, 2011). The teaching adaptations conducted by the teachers according to IEP during the lesson, aim high-level participation of the individuals with special needs (Sucuoğlu and Kargin 2012). This process continues from the beginning to the end of teaching (Özmen, 2009). The education conducted by means of IEP should be adapted according to the needs of the student, pre-acquisitions of the students should be evaluated, teaching materials should be prepared, methods and techniques should be adapted according to the student and also by taking into account other variables (Sucuoğlu and Kargin, 2012). However, in a case study conducted in 2008 , teachers emphasize that there is confusion regarding the role of the general education teacher and the responsibilities of the special education teacher in the IEP development process (Humphrey and Lewis, 2008). It is stated that especially in teachers' fulfillment of their responsibilities or behavioral aspects such as problem-solving skills can be influenced by their attitudes (Baysal, 2003). Since attitude is described as the mental, emotional and behavioral reactions by the individual based on his experience, knowledge, and emotions against himself or any object or social events around him (İnceoğlu, 2010). Therefore, the teachers' perceptions and attitudes towards IEP are deemed as important (Tike, 2007; Karaca, 2018).

In inclusive education, attitudes have an impact on the teacher's emotions, thoughts, and behaviors towards inclusive education (Şekercioğlu, 2010). It is stated that teacher attitudes greatly affect the development of individuals with special needs and these attitudes vary depending on various conditions such as personal characteristics, previous experiences, and competencies of teachers (Todorovic et al., 2011). Teachers involved in inclusive education should have an eager and accepting attitude towards students with special needs in inclusive education (Ataman, 2002). It is stated that general education teachers, who provide academic and social inclusion and have a positive attitude, can provide a more qualified teaching service and create a more qualified classroom environment during the inclusive education process (Gibb and Dyches, 2015). In this respect, teacher attitudes are considered as important in fulfilling the needs of individuals with special needs (EriksBrophy and Whittingham, 2013; Tike, 2007). However, so far research studies focused on the legal requirements of inclusion of students with special needs in general education and the importance of inclusive education (Ünal and Saban, 2017; Çıkılı and Karaca, 2019; Zyoudi, 2006; Haider, 2008). It is observed that the studies conducted in Turkey focused on the difficulties faced by teachers, their views on inclusive education, and their professional competencies regarding the IEP development process (Söğüt and Deniz, 2018; Karaca and Sarı, 2016; Camadan, 2012).

It is observed that general education teachers take a single course on special education in the university, but the majority of these classes do not offer teaching strategies related to special education. It is stated that these undergraduate courses typically focus on the legal responsibilities of teachers with IEP students and their legal rights (DeSimone and Parmar, 2006). In Turkey, these courses were included in all undergraduate teacher training programs with the directive of higher education council issued in 1985 in order for pre-service teachers in faculties of education to gain professional knowledge; in certain departments these courses are among the pedagogy courses in some others there are two separate courses one of which is inclusive education course (Higher Education Board, 2007). When it is considered that the teachers, despite the fact that their duties and responsibilities have a very important place in the IEP team, do not feel themselves as an active member of the IEP team, since they could not participate in the activities related to IEP (Özyürek, 2004; Menlove et al., 2001), the investigation of their attitudes towards the development of IEP program is, therefore, important.

This study is important in terms of the investigation of the sub-dimensions of the IEP attitude scale which are IEP perceptions, IEP task perceptions of preservice teachers in faculties of education in Turkey and the components of IEP. There exist a limited number of studies in Turkey regarding the attitudes of general education teachers and preservice teachers towards the development process of an individualized education program. Therefore, the purpose of this study was determined as investigating the preservice teachers' attitudes towards the development process of IEP in Turkey.

\section{Methodology}

In this section, the research design, participants, and data collection tools incorporated in this study will be explained. 


\subsection{Research Design}

Since the current study aimed to reveal and analyze the attitudes of preservice teachers towards the IEP development process in Turkey according to certain variables, a relational screening model which is one of the descriptive survey models was adopted. The reason for this is that survey models describe a previously existed or currently existing situation. On the other hand, relational screening models provide an understanding of the amount of change between two or more variables (Karasar, 2006).

\subsection{Participants}

The participants of the study were composed of 304 preservice teachers who were senior students at the faculty of education in the 2019-2020 academic year in Turkey. Among these participants, 232 were females (76,3\%), while 72 of them were males $(23,4 \%)$. The demographic information regarding the participants can be seen in Table 1.

Table 1. The demographic information of the participants

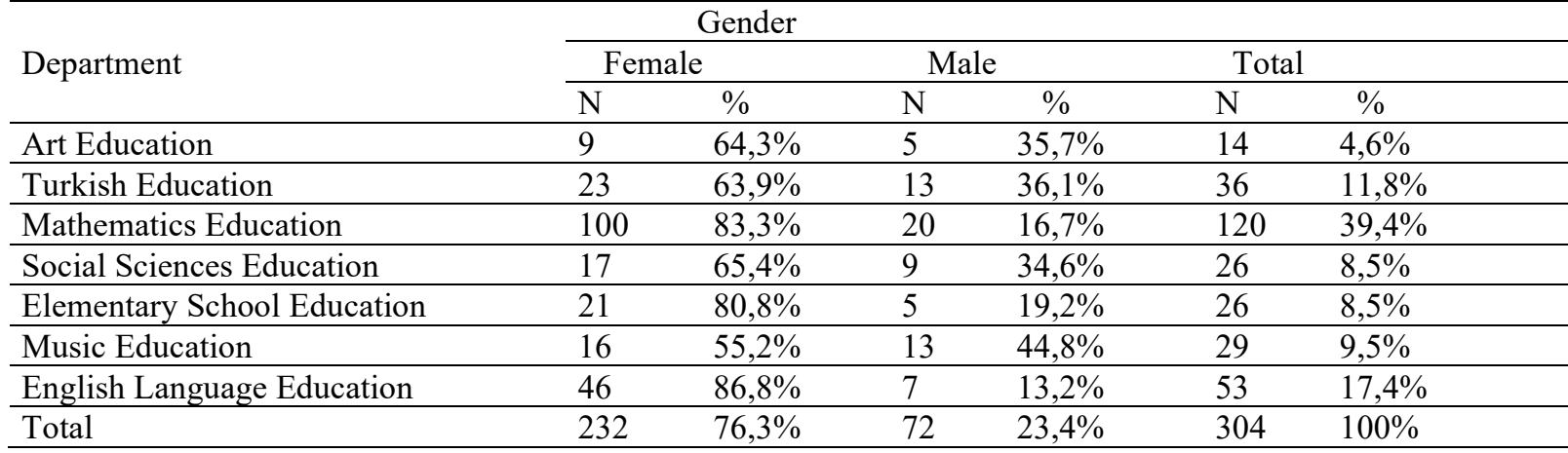

It can be seen in Table 1 that among the 304 participants of the study; 14 participants $(4,6 \%)$ were from Art Education, 36 were from Turkish Education (11,8\%), 120 of the participants $(39,4 \%)$ were from Mathematics Education, 26 of the participants (8,5\%) were from Social Sciences Education, 26 of them $(8,5 \%)$ were from Elementary School Education, 29 of the participants (9,5\%) were from Music Education, and finally, 53 of the participants $(17,4 \%)$ were from English Language Education departments.

\subsection{Data Collection Tool}

The data of the study were collected by means of the Attitudes towards IEP Development Process Scale which was developed by Tike (2007). The scale consisted of 3 dimensions and 15 items. The Principal Component Analysis revealed a 3 -factor structure explaining $61,89 \%$ of the total variance. The Cronbach Alpha which was conducted to determine the internal consistency of the scale revealed .67 for all three factors. A test-retest procedure was implemented with 44 participants after a month interval from the first implementation. After excluding the participants with one or more unanswered items, the test-retest reliability coefficient for the first factor was found as .78, for the second factor .76, and for the third factor, it was found as .82 . The overall score for the scale was .81. In addition, the test split technique was applied on the scale. The reliability of the AIDEPS was analyzed through the Spearman-Brown split-half test and Guttman Split-half method. The reliability coefficient of the first half was found as .78 while for the second half it was found as .82 according to the Guttman split-half method. Similarly, according to the Spearman-Brown split-half test, the reliability score of the first half was found as .87 while for the second half it was .89. In this study, the Cronbach Alpha internal reliability coefficient calculated for the overall attitude scale of the IEP development process was found to be .764 .

Table 2. The evaluation criteria of the attitude scale towards the IEP development process

\begin{tabular}{lll}
\hline Evaluation Criteria & Likert Point & Evaluation Period \\
\hline Strongly Agree (very high) & 1 & $1,00-1,80$ \\
\hline Agree (high) & 2 & $1,81-2,60$ \\
\hline Neutral (mid) & 3 & $2,61-3,40$ \\
\hline Disagree (low) & 4 & $3,41-4,20$ \\
\hline Strongly disagree (very low) & 5 & $4,21-5,00$ \\
\hline
\end{tabular}

The lowest possible score to be obtained from the attitude scale towards the development of IEP is 15 while the highest possible score is 75 . While lower scores from the scale refer to a positive attitude towards the IEP development process, higher scores refer to a negative attitude.

\subsection{Data Analysis}

The data collected in this study was analyzed by means of a statistical program. An independent samples t-test 
was implemented in order to determine whether there exists a statistically significant difference between the participants' attitudes towards the IEP development process and their genders, previous interaction with inclusive students, and having received an inclusion course. A one-way ANOVA was implemented in order to determine a statistically significant difference, if exists, in terms of the participants' knowledge of the regulations regarding inclusive education. In cases of a difference, a Tukey test was implemented in order to reveal the reason for the difference and test the difference between the mean scores. The measures of central tendency (mean, median, peak) were examined in order to determine whether the data reveals a normal distribution and it was found out that these scores are close to each other (see Table 3).

The trend measurements towards the center (average, median and peak value) regarding whether the data meet normality conditions were examined, and it was understood that they were close to each other. Additionally, the skewness and kurtosis coefficients of the data set were determined between +1 and -1 , therefore, the data were considered as having normal distribution (Hair et al., 2006; George and Mallery, 2012).

Table 3. Skewness and kurtosis values

\begin{tabular}{lcl}
\hline & Skewness & Kurtosis \\
\hline IEP Perceptions &, 546 &, 944 \\
\hline The Components of IEP &, 051 &, 138 \\
\hline IEP Task Perceptions &, 205 &, 111 \\
\hline$* \mathrm{~N}=304$ & &
\end{tabular}

\section{Findings}

Table 4. The descriptive statistics regarding the attitude mean scores of preservice teachers

\begin{tabular}{llllll}
\hline & $\mathrm{N}$ & Minimum & Maximum & $\overline{\mathrm{X}}$ & Ss \\
\hline IEP Perceptions & 304 & 1,00 & 4,00 & 2,05 &, 51 \\
\hline The Components of IEP & 304 & 1,00 & 4,00 & 2,30 &, 54 \\
\hline IEP Task Perceptions & 304 & 1,00 & 4,50 & 2,44 &, 61 \\
\hline
\end{tabular}

The mean scores of preservice teachers' attitudes towards the IEP development process can be seen in Table 4. The attitude mean scores of preservice teachers in the sub-dimensions of the attitude scale was determined as $(\bar{X}=2,05)$ regarding the IEP perceptions sub-dimension, $(\bar{X}=2,30)$ in the components of IEP subdimension, and finally, $(\bar{X}=2,44)$ in IEP task perceptions sub-scale which can be considered as high scores.

Table 5. The findings of the comparison between pre-service teachers' genders and their attitudes towards IEP

\begin{tabular}{lllllll}
\hline & Gender & $\mathrm{N}$ & $\overline{\mathrm{X}}$ & $\mathrm{Ss}$ & $\mathrm{t}$ & $\mathrm{p}$ \\
\hline IEP Perceptions & Female & 232 & 12,06 & 2,93 & $-2,581$ & $\mathbf{0 1 0}$ \\
\cline { 2 - 7 } & Male & 72 & 13,13 & 3,50 & & $\mathbf{, 0 0 9}$ \\
\hline \multirow{2}{*}{ The Components of IEP } & Female & 232 & 11,30 & 2,53 & $-2,639$ & \\
\cline { 2 - 7 } & Male & 72 & 12,25 & 3,12 & & $\mathbf{0 0 0}$ \\
\hline IEP Task Perceptions & Female & 232 & 9,50 & 2,34 & $-3,783$ & \\
& Male & 72 & 10,73 & 2,62 & & \\
\hline
\end{tabular}

*p<0,05

Table 5 shows the results of the independent samples t-test regarding the genders of preservice teachers and their attitudes towards the development of IEP. The mean scores of the attitudes towards the development of IEP scale's sub-dimensions were found as follows; females' mean score on the IEP perceptions sub-dimension was $\bar{X}=12,06$ while the males' mean was $\bar{X}=13,13$; in the components of IEP sub-dimension the females' had a $\bar{X}=11,30$ mean, while males' had $\bar{X}=12,25$; finally in the IEP task perceptions sub-scale females' mean score was $\bar{X}=9,50$, while males' score was $\bar{X}=10,73$. The genders of the preservice teachers and their attitudes towards IEP were compared. The results of the independent samples t-test revealed statistically significant differentiation in favor of the female participants in the IEP perceptions $(p<0,05)$, the components of IEP $(\mathrm{p}<0,005)$, and IEP task perception sub-dimensions $(\mathrm{p}<0,001)$. 
Table 6. The statistical findings regarding the comparison of preservice teachers' interaction with inclusion students and their attitudes towards IEP development

\begin{tabular}{lllllll}
\hline Interaction & & $\mathrm{N}$ & $\overline{\mathrm{X}}$ & $\mathrm{Ss}$ & $\mathrm{t}$ & $\mathrm{p}$ \\
\hline IEP perception & Yes & 167 & 12,13 & 2,95 &,- 634 &, 527 \\
& No & 129 & 12,36 & 3,23 & & \\
\hline The components of IEP & Yes & 167 & 11,36 & 2,81 & $-1,298$ &, 195 \\
& No & 129 & 11,77 & 2,54 & & \\
\hline IEP task perception & Yes & 167 & 9,77 & 2,52 &,- 109 &, 914 \\
& No & 129 & 9,80 & 2,45 & & \\
\hline
\end{tabular}

Table 6 reveals the comparison of preservice teachers' interaction with inclusion students and their attitudes towards IEP development. When the mean scores of the participants regarding their attitudes towards IEP considered, it can be seen that the participants who had previous interaction had $\bar{X}=12,13$ in IEP perceptions sub-dimension, the ones who did not interact had $\bar{X}=12,36$, in the components of IEP sub-dimension, and the participants with previous interaction had $\bar{X}=11,36$, the ones who did not interact had $\bar{X}=11,77$, finally, the participants with previous interaction with inclusion students had $\bar{X}=9,77$ in IEP task perceptions subdimension while the ones with no previous interaction had $\bar{X}=9,80$. The independent samples t-test revealed no statistically significant relationship between the preservice teachers' previous interaction with inclusion students and their attitudes towards the development of IEP $(p>0,05)$.

Table 7. The statistical findings regarding the comparison of preservice teachers' training on inclusive education and their attitudes towards the development of IEP

\begin{tabular}{lllllll}
\hline \multicolumn{2}{l}{ Training on inclusive education } & $\mathrm{N}$ & $\overline{\mathrm{X}}$ & $\mathrm{Ss}$ & $\mathrm{t}$ & $\mathrm{p}$ \\
\hline IEP perceptions & Yes & 194 & 12,07 & 2,96 & $-1,743$ &, 082 \\
& No & 109 & 12,71 & 3,27 & & \\
\hline \multirow{2}{*}{ The components of IEP } & Yes & 194 & 11,16 & 2,62 & $-2,249$ & $\mathbf{0 2 5}$ \\
& No & 109 & 11,98 & 2,80 & &, 064 \\
\hline IEP task perception & Yes & 194 & 9,60 & 2,43 & $-1,871$ & \\
& No & 109 & 10,15 & 2,49 & & \\
\hline
\end{tabular}

* $\mathbf{p}<\mathbf{0 , 0 5}$

Table 7 reveals the statistical findings regarding the comparison of preservice teachers' training on inclusive education and their attitudes towards the development of IEP. When the mean scores of the participants regarding their attitudes towards IEP is considered, it can be seen that the participants with previous education had $\bar{X}=12,07$, the ones with no previous education had $\bar{X}=12,71$ in the IEP perceptions sub-dimension, similarly in the components of IEP sub-dimension the participants with previous education had $\bar{X}=11,16$, the ones with no previous education had $\bar{X}=11,98$, finally, in IEP task perceptions sub-dimension the participants with previous education had $\bar{X}=9,60$ while the ones with no previous education had $\bar{X}=10,15$. The results of the independent samples t-test revealed no statistically significant difference in IEP perception and IEP task perceptions sub-dimensions between the preservice teachers with previous education on inclusive students and the ones with no previous education ( $p>0,05)$, however, in the components of IEP sub-dimension a statistically significant difference was found $(p<0,05)$. It is clear that the statistically significant difference is in favor of the preservice teachers with previous education on inclusive education. 
Table 8. The statistical findings regarding the comparison of preservice teachers' knowledge of the regulations and their attitudes towards IEP development

\begin{tabular}{|c|c|c|c|c|c|c|c|}
\hline & & $\mathrm{N}$ & $\bar{X}$ & Ss & $\mathrm{F}$ & $\mathrm{p}$ & $\begin{array}{l}\text { Significant } \\
\text { Difference }\end{array}$ \\
\hline \multirow{4}{*}{ IEP perceptions } & 1.Knowledgeable & 29 & 10,82 & 2,33 & 5,044 & $\mathbf{0 , 0 0 7}$ & $1-2$ \\
\hline & $\begin{array}{l}\text { 2.Partial } \\
\text { knowledge }\end{array}$ & 193 & 12,28 & 3,02 & & & $1-3$ \\
\hline & 3.No knowledge & 82 & 12,92 & 3,37 & & & \\
\hline & Total & 304 & 12,32 & 3,1 & & & \\
\hline \multirow{4}{*}{$\begin{array}{l}\text { The components } \\
\text { IEP }\end{array}$} & 1.Knowledgeable & 29 & 9,75 & 3,21 & 7,878 &, 000 & $1-2$ \\
\hline & $\begin{array}{l}\text { 2.Partial } \\
\text { knowledge }\end{array}$ & 193 & 11,58 & 2,51 & & & $1-3$ \\
\hline & 3.No knowledge & 82 & 12,01 & 2,73 & & & \\
\hline & Total & 304 & 11,52 & 2,7 & & & \\
\hline \multirow{4}{*}{ IEP task perceptions } & 1.Knowledgeable & 29 & 9,4 & 2,86 & 1,896 & 0,152 & \\
\hline & $\begin{array}{l}\text { 2.Partial } \\
\text { knowledge }\end{array}$ & 193 & 9,67 & 2,37 & & & \\
\hline & 3.No knowledge & 82 & 10,22 & 2,5 & & & \\
\hline & Total & 304 & 9,79 & 2,46 & & & \\
\hline
\end{tabular}

$* \mathbf{p}<\mathbf{0 , 0 5}$

Table 8 reveals the findings regarding the comparison of preservice teachers' knowledge of the regulations and their attitudes towards IEP development. When the mean scores of the participants regarding their attitudes towards the development of IEP is considered, it was revealed that the participants with knowledge of the regulations had $\overline{\mathrm{X}}=10,82$, the ones with partial knowledge of the regulations had $\overline{\mathrm{X}}=12,28$, the participants with no knowledge of the regulations had $\bar{X}=12,92$ in terms of the IEP perceptions sub-dimension. Similarly, in the components of IEP sub-dimension, the participants with knowledge of the regulations had $\bar{X}=9,75$, the ones with partial knowledge had $\overline{\mathrm{X}}=11,58$, and the participants with no knowledge of the regulations had $\overline{\mathrm{X}}=12,01$. Finally, in the IEP task perception dimension, the participants with knowledge of the regulations had $\bar{X}=9,40$, the ones with partial knowledge of the regulations had $\bar{X}=9,67$, while the ones with no knowledge of the regulations had $\overline{\mathrm{X}}=10,22$. An ANOVA test was implemented on the data. Additionally, the Tukey test, which is one of the Post Hoc tests, was implemented. A statistically significant difference was found between the participants with the knowledge of inclusive education regulations and with the ones who had no knowledge of the regulations regarding the IEP perceptions sub-dimension of the attitudes towards IEP development scale. The results revealed that the difference was in favor of the participants with knowledge of the inclusive education regulations, to be clearer, the participants with knowledge of the regulations were found to have more positive attitudes compared to the participants with partial or no knowledge of the regulations.

\section{Discussion and Conclusion}

There exist studies regarding the attitudes of teachers and pre-service teachers towards individualized education program (Lee-Tarver, 2006; Rotter, 2014; Kosko and Wilkins, 2009). However, the current study investigated the attitudes of preservice teachers in Turkey towards the development of the individualized education program. The results of the study revealed that the participants had positive attitudes regarding the development of the IEP sub-dimensions as IEP perceptions, the components of IEP, and IEP task perceptions. A study conducted in Alabama and Georgia, the USA, revealed that most of the general education teachers perceived the individualized education program as a beneficial instrument to sustain the programs (Lee-Tarver, 2006). Another study conducted in New Jersey to investigate the benefits of IEP in teaching revealed that teachers had positive attitudes towards IEP (Rotter, 2014). There are also studies that revealed positive attitudes and positive views of teachers towards inclusive education (Güleryüz and Özdemir, 2015; Gök and Erba, 2011; Sargin and Sünbül, 2002; Bozarslan and Batu, 2014; Rakap et al., 2016). The current study also revealed that the teachers in inclusive education had positive attitudes towards the IEP development process.

The results of the study revealed that female preservice teachers had significantly higher positive attitudes towards the IEP perceptions, the components of IEP and IEP task perception sub-dimensions of IEP development process compared to male preservice teachers. Another study also revealed that the attitudes of female teachers towards IEP were significantly higher compared to male teachers (Akçamete and Kargin, 1994). However, there exist some other studies that found out no statistically significant differences between female and male teachers regarding the IEP development process (Tike, 2007). These controversial findings refer that the findings regarding the gender variables in attitudes towards IEP were not sufficient to propose a solid 
explanation, and the issue needs to be investigated in relation to other variables.

The results of the study revealed no statistically significant difference between the previous interaction with inclusive students and the sub-dimensions of the attitudes towards IEP development. In this regard, previous studies revealed that teachers (Yılmaz and Batu, 2016) and preservice teachers (Çıkılı and Karaca, 2019) who had previous interaction with inclusive students had less anxiety while more positive feelings, on the other hand, their attitudes revealed no significant difference.

At the end of the study, the preservice teachers' training on inclusive education and their attitudes towards the development of IEP was compared. The results revealed that in the components of IEP sub-dimension the participants with previous education on inclusive education were found significantly higher. Therefore, it is considered that integrating a course on inclusive education into every teacher training program would be beneficial (Yavuz, 2005; Battal, 2007; Camadan, 2012). In IEP perceptions and IEP task perceptions subdimensions, no statistically significant difference was found. These findings in the two mentioned subdimensions may be related to the insufficiency of objectives of the course for the students. The previous studies revealed that preservice teachers did not feel prepared enough for inclusive education and they wanted more courses on inclusive education (Maccini and Gagnon, 2006; Pindiprolu et al., 2007, Desimone and Parmar, 2006). It is stated that in order for the general education teachers to be able to implement programs for individuals with special needs there is a need to acquire special education strategies that they can adapt to their subjects and objectives (Maccini and Gagnon, 2006). A study conducted by Küçüker et al. (2002) revealed that the Guidance and Research Center staff's attitudes towards the IEP development process differ according to their previous education. Teachers who participated in training programs revealed higher positive attitudes towards the IEP development process.

The study included a comparison of the preservice teachers' knowledge of the regulations and their attitudes towards IEP development. At the end of the study, it was found out that the preservice teachers who are knowledgeable about the IEP had higher positive attitudes in the components of IEP and IEP perceptions subdimensions compared to the ones who have no knowledge of the regulations. A study conducted by Ç1kılı and Karaca (2019) revealed that the preservice teachers who had the knowledge of the inclusive education had higher emotional state and lower anxiety levels. Another study revealed that general education teachers were knowledgeable about the regulations regarding inclusive education and their views regarding inclusive education were positive (Y1lmaz and Batu, 2016), on the other hand, teachers who did not have any education on IEP thought that IEP was not necessary (Ateş, 2017). A study by Kaya (2003) revealed that insufficient knowledge of the administrators and teachers regarding inclusive education caused them to develop a negative attitude towards inclusive education. The results of the current study revealed no statistically significant difference between the knowledge of the regulation and IEP task perception sub-dimension. The previous studies revealed that the policies and practices do not match when it comes to special education (Çitil, 2009). The studies from all around the world confirm this point (Lazarus et al., 2007; Gartland, 2007; Kontu and Pirttimaa, 2008). It can be stated that the legal regulations were properly designed, however, the difficulties during the implementation (TekinErsan and Ata, 2017; Y1lmaz and Batu, 2016) can be claimed to be the factor that prevents a possible the difference between preservice teachers' knowledge of the regulations and the IEP task perceptions subdimension. Therefore, it can be claimed that the findings of the previous studies support the current study findings.

It is highlighted that the attitudes of general education teachers who take part in the implementation of the IEP in inclusive education towards IEP development and implementation can directly affect the education of the students with special needs (Avcioğlu, 2011). For this reason, it is considered that the improvement of IEP implementation is an important responsibility (Agbenyega and Sharma, 2014). In this respect, future studies should investigate the professional qualifications and IEP perceptions of general education teachers who teach in inclusive education classes. Additionally, future studies should be conducted to find proof on how IEP use can lead to better learning outcomes for students.

\section{References}

Agbenyega, J. S., \& Sharma, U. (2014). Leading inclusive education: Measuring 'effective' leadership for inclusive education through a Bourdieuian lens. In C. Forlin \& T. Loreman (Eds.), Measuring inclusive education (pp. 115-132). United Kingdom: Emerald Group Publishing Limited.

Akçamete, G., \& Kargın, T. (1994). Hizmet içi eğitim programının öğretmenlerin işitme engelli çocuklara yönelik tutumlarına etkisi [The effect of in-service training program on teachers' attitudes towards hearing impaired children]. Özel Eğitim Dergisi 1 (4), 13-19.

Allen, K. E., \& Cowdery, G. E. (2015). The exceptional child: Inclusion in early childhood education (8th ed.). Stamford, CT: Cencage Learning.Allyn \& Bacon.

Al-Zyoudi, M. (2006). Teachers' attitudes towards inclusive education in Jordanian schools. International Journal of Special Education, 21(2), 55-62. 
Aral, N. (2011). Okul öncesi eğitimde kaynaştırma [Inclusion in pre-school education]. İstanbul: Morpa Yayınları.

Ataman, A. (2002). Kaynaştırmada Sınıf Öğretmenlerinin Rolleri ve Yetiştirilme Sorunlarl [The Roles of Classroom Teachers in Inclusion and Training Problems]. XI. Özel Eğitim Kongresi Bildirileri. Konya. Eğitim Kitabevi.

Ateş, M. (2017). Bilim ve sanat merkezlerinde görev yapan Türkçe öğretmenlerinin bireyselleştirilmiş eğitim planı hakkındaki görüşlerinin incelenmesi [Examining the opinions of Turkish teachers working in science and art centers about the individualized education plan]. Mehmet Akif Ersoy Üniversitesi, Eğitim Fakültesi Dergisi. 42(1), 211-225.

Avcıoğlu, H. (2011). Zihin engelliler sınıf öğretmenlerinin bireyselleştirilmiş eğitim programı (BEP) hazırlamaya ilişkin görüşleri [Opinions of teachers with intellectual disabilities about preparing an individualized education program (IEP)]. Ankara Üniversitesi Eğitim Bilimleri Fakültesi Özel Ĕ̆itim Dergisi, 12(01), 39-56.

Baldiris N., S., Zervas, P., Fabregat G., R., \& Sampson, D. G. (2016). Developing teachers' competences for designing inclusive learning experiences. Educational Technology \& Society, 19(1), 17-27.

Battal, İ. (2007). Sını Öğretmenlerinin ve Branş Öğretmenlerinin Kaynaştırma Ĕgitimine İlişkin Yeterliliklerinin Değerlendirilmesi (Uşak ili örneği)[ Evaluation of Adequacy of Primary School Teachers and Branch Teachers Regarding Inclusive Education (Example of Uşak province)], Yayınlanmamış Yüksek Lisans Tezi, Afyonkarahisar Kocatepe Üniversitesi, Sosyal Bilimler Enstitüsü, Afyon.

Batu, S., Çolak, A., \& S. Odluyurt. (2012), Özel Gereksinimli Çocukların Kaynaştırılması [Inclusion of Children with Special Needs]. Ankara: Vize Yayıncıl1k.

Batu, E. S. (2006). Bireyselleştirilmiş eğitim programlarında ekip çalışmalarına yer verilmesi. O. Gürsel (Ed.), Bireyselleştirilmiş eğitim programları (s. 31-44) [Including team work in individualized education programs. O. Gürsel (Ed.), Individualized education programs (p. 31-44)]. Eskişehir: Anadolu Üniversitesi Yayınları.

Batu, E. S. (2015). Kaynaştırma, destek hizmetler ve kaynaştırmaya hazırlık etkinlikleri [Inclusion, support services and preparation activities for 1nclusion]. Ankara Üniversitesi Özel Ĕgitim Dergisi, 2(04). doi: 10.1501/Ozlegt_0000000050.

Batu, E. S., Cüre, G., Nar, S., Gövercin, D., \& Keskin, M. (2018). Türkiye'de ilkokul ve ortaokullarda yapılan kaynaştırma araştırmalarının gözden geçirilmesi [The revision of inclusion research carried out in elementary and secondary schools in Turkey]. Ankara Üniversitesi Eğitim Bilimleri Fakültesi Özel Eğitim Dergisi, 19(3), 577-614. doi: 10.21565/ozelegitimdergisi.336925.

Baysal, Z. N. (2003). İlköğretim Sosyal Bilgiler Dersinde Öğretmen Tutumlarının Problem Çözmeye Dayalı Ögrenmeye Etkisi [The Effect Of Teacher Attitudes On Problem Solving Learning In Elementary School Social Studies Lesson]. Marmara Üniversitesi, Eğitim Bilimleri Enstitüsü, Doktora Tezi.

Bozarslan, B. ve Batu, E. S. (2014). Özel anaokullarında çalışan eğiticilerin okulöncesi dönemde kaynaştırma ile ilgili görüş ve önerileri [Views and suggestions of educators working in private kindergardens about inclusion in preschool period]. Abant İzzet Baysal Üniversitesi Eğitim Fakültesi Dergisi, 14(2), 86-108.

Camadan, F. (2012). Sınıf öğretmenleri ve sınıf öğretmeni adaylarının kaynaştırma eğitimine ve BEP hazırlamaya ilişkin öz-yeterliklerinin belirlenmesi [Determining the self-efficacy of elementary school teachers and elementary school teacher candidates for inclusive education and preparing IEP]. Elektronik Sosyal Bilimler Dergisi, 11(39), 128-138.

Çıkılı, Y., \& Karaca, M. A. (2019). Examination of teacher candidates'attitudes, emotions, and anxieties regarding inclusive education by different variables. European Journal of Special Education Research.

Çolak, A., Vuran, S., \& Uzuner, Y. (2013). Kaynaştırma uygulanan bir ilköğretim sınıfındaki sosyal yeterlik özelliklerinin betimlenmesi ve iyileştirilmesi çalışmaları [Studies to describe and improve the social competency characteristics in a primary school where inclusion is applied]. Ankara Üniversitesi Ĕgitim Bilimleri Fakültesi Özel Eğitim Dergisi, 15(Özel Sayı) 33-49.

Darden, E. C. (2013). What's so special about an IEP? Phi Delta Kappan, 94(6), 66-67.

DeSimone, J. R., \& Parmar, R. S. (2006). Middle school mathematics teachers' beliefs about inclusion of students with learning disabilities. Learning Disabilities Research \& Practice, 21(2), 98-110.

Erden, M. (1998). Ĕgitimde program değerlendirme [Curriculum evaluation in Education]. Anı Yayıncılık.

Eriks-Brophy, A., \& Whittingham, J. (2013). Teachers' perceptions of the inclusion of children with hearing loss in general education settings. American annals of the deaf, 158(1), 63-97.

Friend, M., \& Cook, L. (2010). Interactions: Collaboration skills for school professionals. New York: Longman Publishing Group.

Foster, S., \& Cue, K. (2008). Roles and responsibilities of itinerant specialist teachers of deaf and hard of hearing students. American Annals of the Deaf, 153(5), 435-449.

Gartland, D. (2007). The documentation disconnect for students with learning disabilities: improving access to 
postsecondary disability services. a report from the national joint committee on learning disabilities. Jully, 265-274.

George, D., \& Mallery, P. (2012). SPSS Statistics 21: Step by Step. Boston: Allynand Bacon.

Gibb, G. S., \& Dyches, T. T. (2015). IEPs: Writing quality individualized education programs. Pearson.

Gibson, S. (2015) When rights are not enough: What is? Moving towards new pedagogy for inclusive education within UK universities, International Journal of Inclusive Education,19 (8), 875-886. Doi: 10.1080/13603116.2015.1015177.

Gök, G., \& Erba, D. (2011). Okulöncesi eğitimi öğretmenlerinin kaynaştırma eğitimine ilişkin görüşleri ve önerileri [Opinions and suggestions of preschool education teachers about inclusive Education]. International Journal of Early Childhood Special Education, 3(1), 66-87.

Güleryüz, B., \& Özdemir, M. (2015). Sınıf öğretmenlerinin ve sınıf öğretmeni adaylarının kaynaştırma eğitimine ilişkin tutumlarının incelenmesi [Examination of attitudes of elementary school teachers and elementary school teacher candidates related to inclusion Education]. Uşak Üniversitesi Sosyal Bilimler Dergisi, 8(3), 53-64.

Haider, S. I. (2008). Pakistani teachers' attitudes towards inclusion of students with special educational needs. Pak J Med Sci, 24(4), 632-6.

Hair, J. F. Jr., Black, W. C., Babin, B. J., Anderson, R. E., \& Tatham, R. L. (2006). Multivariate data analysis. (6. Baskl). Upper Saddle River, NJ: Pearson/Prentice Hall.

Higher Education Board (2007). Öğretmen Yetiştirme Lisans Programı [Teacher Training Undergraduate Program],https://www.yok.gov.tr /Documents/Yayinlar/Yayinlarimiz/e gitim-fakultesi -ogretmen yetistirme-lisans -programlari.pdf (date of access: 27.01.2020).

Humphrey, N., \& Lewis, S. (2008). What does 'inclusion' mean for pupils on the autistic spectrum in mainstream secondary schools? Journal of Research in Special Educational Needs, 8(3), 132-140.

İnceoğlu, M. (2010). Tutum, algl ve iletişim [Attitude, perception and communication]. Beykent Üniversitesi Yayınevi, İstanbul

Johns, B., Crowley, \& P., Guetzloe, E. (2002). Planning the IEP for students with emotional and behavioral disorders. Focus On Exceptional Children. Vol. 34. No.9.

Karaca, M.A. (2018). Kaynaştırma Ĕ̆itimi Programının Öğretmenlerin Kaynaştırma Uygulamalarındaki Mesleki Yeterliliklerine Etkisi [The Effect of Inclusive Education Program on Teachers' Professional Competencies in Inclusive Practices], Necmettin Erbakan Üniversitesi, Eğitim Bilimleri Enstitüsü, Yüksek Lisans Tezi.

Karaca, M.A., \& Sar1, H. (2016) The evaluation of the adequacy of knowledge of teachers working in rehabilitation centers on individualized education program, International Conference Venice/ Italy, Kongre Kitapçı̆̆ 1 .

Karaca, M.A., \& Efilti, E. (2019) Zihin engelli çocuğu olan annelerin normal gelişim gösteren çocuklarıyla iletisimlerinin incelenmesi [Examination of mothers with intellectual disabled children communication with their normally developing children], USBİK.

Karasar, N. (2006). Bilimsel araştırma yöntemi [Scientific research method]. 16. Baskl, Ankara: Nobel Yayincilik.

Kargın, T. (2007). Eğitsel değerlendirme ve bireyselleştirilmiş eğitim programı hazırlama süreci [Educational evaluation and individualized education program preparation process]. Ankara Üniversitesi Eğitim Bilimleri Fakültesi Özel Ĕ̈itim Dergisi, 8 (1), 1-13.

Kaya, U. (2003). İlköğretim Okulu Yöneticilerinin, Sını Ö̆gretmenlerinin ve Rehber Öğretmenlerin Kaynaştırma İle İlgili Bilgi, Tutum ve Uygulamalarının Incelenmesi (Yayınlanmamış Yüksek Lisans Tezi) [Examination Of Elementary School Administrators, Elementary School Teachers And Counselors' Knowledge, Attitudes And Practices About Inclusion (Unpublished Master's Thesis)]. Gazi Üniversitesi, Eğitim Bilimleri Enstitüsü, Ankara.

Kontu, E. \& Pirttimaa, R. (2008). Short report. the assessment of severely intellectually disabled students. European Journal of Special Needs Education. 23 (1). Feb., 75-80.

Kosko, K. W., \& Wilkins, J. L. (2009). General educators' in-service training and their self-perceived ability to adapt instruction for students with IEPs. Professional Educator, 33(2).

Küçüker, S., Kargın, T. \& Akçamete, G., (2002). Rehberlik ve Araştırma Merkezi elemanlarının özel eğitim hizmetleri yönetmeliğine ilişkin görüşlerinin ve yeterlilik algılarının geliştirilmesi [Improving the views and competence perceptions of the Guidance and Research Center staff on the special education services regulation]. Educational Sciences and Practice 1. (1), 101-113. Ankara

Lazarus, S.S. \& Thurlow, M.L., \& Christensen, L.L., \& Cormier, D. (2007). Synthesis Report 67. States' Alternate Assessments Based on Modified Achievement Standarts. AA-MAS) Dec.

Lee-Tarver, A. (2006). Are individualized education plans a good thing? a survey of teachers' perceptions of the utility of IEPs in regular education settings. Journal of Instructional Psychology, 33(4). 
Lewis, R., \& Doorlag, D. (2011). Teaching students with special needs in general education classrooms (8th ed.). New York: Pearson.

Maccini, P., \& Gagnon, J. C. (2006). Mathematics instructional practices and assessment accommodations by secondary special and general educators. Council for Exceptional Children, 72(2), 217-234.

Menlove, R. R., Hudson, P. J., \& Suter, D. (2001). A field of IEP dreams increasing general education teacher participation in the IEP Development Process. Teaching Exceptional Children, 33(5), 28-33.

Milsom, A., Goodnough, G., \& Akos, P. (2007). School counselor contributions to the individualized education program (IEP) process. preventing school failure: Alternative Education for Children and Youth, 52(1), 1924.

Mueller, T. G., \& Vick, A. M. (2019). An Investigation of facilitated individualized education program meeting practice: promising procedures that foster family-professional collaboration. Teacher Education and Special Education, 42(1), 67-81.

National Education Statistics Formal Education (2019), sgb.meb.gov.tr/meb iys dosyalar /2019 09/30102730 meb_istatistikleri_orgun_egitim_2018_2019.pdf (date of access: 17.01.2020).

Odluyurt, $\overline{\mathrm{S}}$., \& Batu, $\overline{\mathrm{S}}$. (2013). Kaynaştırmanın başarısını etkileyen faktörler. özel gereksinimli öğrencilerin kaynaştırılması ögretmen el kitabı. Ankara. Vize Basın Yayın. [Factors affecting the success of inclusion]

Özbek, R. (2005). Eğitim programlarının bireyselleştirilmesinin sebepleri [Reasons for individualizing educational programs]. Elektronik Sosyal Bilimler Dergisi, 4(11).

Özyürek, M. (2004). Bireyselleştirilmiş ĕgitim programı temelleri ve geliştirilmesi (1. baskl) [Individualized education program fundamentals and development (1st edition)]. Ankara:Kök Yayıncılık.

Özyürek, M. (2012). Bireyselleştirilmiş Eğitim Programını Geliştirme ve Temelleri (8. baskl) [Development and Fundamentals of Individualized Education Program (8th edition)]. Ankara: Kök Yayıncılık.

Pindiprolu, S., Peterson, S., \& Bergloff, H. (2007). School personnel's professional development needs and skill level with functional behavior assessments in ten Midwestern states in the United States: Analysis and issues. The Journal of the International Association of Special Education, 8(1), 31-42.

Rakap, S., Parlak-Rakap, A., \& Aydin, B. (2016). Investigation and comparison of Turkish and American preschool teacher candidates' attitudes towards inclusion of young children with disabilities. International Journal of Inclusive Education, 20(11), 1223-1237.

Official Newspaper, (1997). 573 Sayılı Özel Ĕ̆itim Hizmetleri Hakkında Kanun Hükmünde Kararname [Decree Law No. 573 on Special Education Services]. (23011) www.mevzuat.basbakanlık.gov.tr.

Rotter, K. (2014). IEP use by general and special education teachers. Sage Open, 4(2), 2158244014530410.

Sanjeev, K. \& Kumar, K. (2007). Inclusive education in India. Electronic Journal for Inclusive Education, 2(2), $1-15$.

Sargın, N., \& Sünbül, A. M. (2002). Okul öncesi dönemde kaynaştırma eğitimine ilişkin öğretmen tutumlarl: Konya ili örneği [Teacher attitudes towards inclusive education in preschool period: Example of Konya province]. Doğu Akdeniz Üniversitesi, XI. Eğitim Bilimleri.

Sarıöz, O. (2019). The opinions of primary school teachers on individualized education. Electronic Turkish Studies, 14(6).

Söğüt, D. A., \& Deniz, S. (2018) Sınıf öğretmenlerinin bireyselleştirilmiş eğitim programı (bep) hazırlamada karşılaştıkları güçlükler ve kaynaştırma uygulamalarına ilişkin görüşlerinin değerlendirilmesi [Evaluation of elementary school teachers' difficulties encountered in preparing individualized education program (IEP) and their views on inclusion practices]. Erzincan Üniversitesi Eğitim Fakültesi Dergisi, 20(2), 423-443.

Sucuoğlu , B., \& Kargın , T. (2012). Ilköğretim'de kaynaştırma uygulamaları.(2. baskl) [ınclusion practices in primary education (2nd edition)] Ankara: Kök Yayıncılık.

Şekercioğlu, B. (2010). İlköğretim II. Kademe Branş Öğretmenlerinin, KaynaşTırma Uygulamalarında Karşllaştıkları Sorunlar Ille İlgili Görüşleri [Opinions of 2nd Level Primary School Teachers About The Problems Encountered in Inclusive Practices], Yüksek Lisans Tezi, Ankara: Gazi Üniversitesi.

Tekin-Ersan, D., \& Seda, ATA. (2017). Okul öncesi öğretmenlerinin bireyselleştirilmiş eğitim programı hazırlanmasına ilişkin görüşleri [Preschool teachers' views on the preparation of an individualized education program]. Trakya Üniversitesi Ĕ̈itim Fakültesi Dergisi, 8(1), 162-177.

The Ministry of National Education, (2018). Özel ĕgitim hizmetleri yönetmeliği [Special education services regulation]. Milli Eğitim Basımevi. Ankara.

The Ministry of National Education, (2013). Birlikte başarırız bütünleştirme kapsamında eğitim uygulamaları ögretmen kllavuz kitabu [Together we succeed in the context of integration educational practices teacher guide book]. Ankara: MEB Özel Eğitim ve Rehberlik Hizmetleri Genel Müdürlüğü.

Tike, L. Y. (2007). Sınıf Öğretmenleri, Rehber ve ÖĞretmenler ve RAM ÇalışAnlarının BireyselleşTirilmiş Ĕ̈itim Programları Hazırlama Sürecine İlişkin Tutumları ve Karşılaşabilecekleri Güçlüklerin Belirlenmesi [Determining The Attitudes And Difficulties That Elementary School Teachers, Counselors And RAM Staff Have Towards The Process Of Preparing Individualized Education Programs] (Doctoral dissertation, 
Ankara Üniversitesi Eğitim Bilimleri Enstitüsü Özel Eğitim Anabilim Dalı Özel Eğitim Bilim Dalı.

Todorovic, J., Stojiljkovic, S., Ristanic, S., \& Djigic, G. (2011). Attitudes towards inclusive education and dimensions of teacher's personality. Procedia-Social and Behavioral Sciences, 29, 426-432.

Turnbull, A., Turnbull, R., Shank, M., Smith, S. \& Leal, D. (2002). Exceptional lives: Special education in today's schools (3rd ed). New Jersey: Merrill.

Ünal, F., \& Saban, A. İ. (2017). Kaynaştırma uygulamasının yapıldığı sınıflarda öğretmenlerin kaynaştırmaya yönelik tutumlar1-1 [The attitudes of teachers towards inclusion in classes where inclusion practices are made]. Çukurova Üniversitesi Sosyal Bilimler Enstitüsü Dergisi, 23(1), 388-405.

Yavuz, C. (2005). Ankara ilindeki Okulöncesi Eğitim Kurumlarında Sürdürülen Kaynaştırma Uygulamalarının Değerlendirilmesi [Evaluation of Inclusion Practices in Preschool Education Institutions in Ankara], Yayınlanmamış Yüksek Lisans Tezi, Gazi Üniversitesi, Eğitim Bilimleri Enstitüsü. Ankara.

Yıkmış. A. (2013). Bireyselleştirilmiş eğitim programlarının (BEP) hazırlanması [Preparation of ındividualized education programs (bep)]. özel eğitim (113). Ankara:Maya Akademi Yayın Dağıtım Eğitim Danışmanlık.

Yılmaz, E., \& Batu, E. S. (2016). Farklı branştan ilkokul öğretmenlerinin bireyselleştirilmiş eğitim programı, yasal düzenlemeler ve kaynaştırma uygulamaları hakkındaki görüşleri [Opinions of elementary school teachers from different branches about individualized education program, legal regulations and inclusion practices]. Ankara Üniversitesi Ĕ̈itim Bilimleri Fakültesi Özel Ĕ̆itim Dergisi, 17(03), 247-268. 